\title{
Evaluation of Integrated Disease Management Practices against the Powdery Mildew, Anthracnose and Die Back Diseases of Chilli
}

\author{
S.C. Yadav*, S.C. Mukherjee and RS Netam \\ Saheed Gundadhoor College of Agriculture and Research Station, IGKV, Jagdalpur, \\ Bastar- 494001, Chhattisgarh, India \\ *Corresponding author
}

\begin{tabular}{|c|c|}
\hline & A B S T R A C T \\
\hline \multirow{5}{*}{$\begin{array}{l}\text { Ke y w o r d s } \\
\text { Anthracnose, } \\
\text { Die back, } \\
\text { Powdery mildew, } \\
\text { Colletotrichum, } \\
\text { IDM, Chilli }\end{array}$} & \multirow{8}{*}{$\begin{array}{l}\text { The integrated disease module were evaluated for management of } \\
\text { anthracnose, die back and Powdery mildew diseases on two newly hybrid } \\
\text { preferred by the farmers NS-1701 (Namdhari Seed Co.) and VNR- } 435 \\
\text { (VNR Seed Co.) and one wide spread variety Tejswini. Disease control by } \\
\text { IDM was significantly effective in hybrid varieties NS-1701, VNR-435 and } \\
\text { Tejaswini as compared to control (without IDM). IDM module was found } \\
\text { effective in reducing disease incidence and higher fruit yield with net } \\
\text { return. IDM module reduced powdery mildew, anthracnose on leaves, fruit } \\
\text { infection and die back diseases incidence as } 54.3 \%, 47.2 \%, 39.0 \% \text {, and } \\
67.1 \% \text {, respectively, and increased fruit yields by } 19.1 \% \text { in all three tested } \\
\text { varieties of hybrid NS-1701, VNR-435 as compared to without IDM. Cost } \\
\text { benefit ratio and net return in per hectare was recorded higher of in IDM } \\
\text { fields (1:2.13, Rs. } 96020 /-) \text { as compared to without IDM fields as (1:1.86, } \\
\text { Rs. } 74100 /-) \text { at farmers fields of Bastar District. }\end{array}$} \\
\hline & \\
\hline & \\
\hline & \\
\hline & \\
\hline Article Info & \\
\hline $\begin{array}{l}\text { Accepted: } \\
\text { 20 January } 2017 \\
\text { Available Online: } \\
\text { 10 February } 2017\end{array}$ & \\
\hline & \\
\hline
\end{tabular}

\section{Introduction}

Chilli (Capsicum annum L) is also known as red pepper is an important cash crop in India. It is grown for its pungent fruits. Both green and ripe fruits are used to impart pungency to the food. As a condiment, it has become indispensable in every house. It is also used medicinally, chutneys and pickles. India has become world's largest producer and exporter of chilli by exporting to USA, Canada, UK, Saudi Arabia, Singapore, Malaysia, Germany and many other countries of world. India contributes $25 \%$ of the world's total production of chilli. Indian chillies have been dominating international chilli market. In India, chilli is mainly grown in state of Andhra Pradesh, Maharashtra, Karnataka, Gujarat, Tamil Nadu, Orissa and Chhattisgarh. In Bastar region of Chhattisgarh due to its suitable environment and soils the chilli production and its area is increase day by day and mainly grow for domestic exports via Raipur, Durg, Nagpur, Hyderabad etc.

Chilli in India suffers from two serious fungal diseases anthracnose ripe fruit rot and die back both caused same fungus. Different 
species of Colletotrichum, namely C. capsici, C. gloeosporioides and $C$. acutatum are known to cause anthracnose in chilli in India. Chilli anthracnose was first reported in India from Coimbatore of Madras Presidency (Sydow, 1913). Anthracnose disease appears as small circular spot that coalesce to form large elliptical spot on fruits and leaves. Under severe conditions, defoliation of affected plants occurs. Kim et al., (2004) reported that different species cause diseases of different parts of the chilli plant. The disease has been observed to occur in three phases; seedling blight or damping off, leaf spot, die back and anthracnose or fruit rot. Fruits with diseased lesions have reduced marketability (Bosland and Votava, 2003; Manandhar et al., 1995). Chowdhary (1957) was also reported that 12 to 32 per cent of fruit were found affected by anthracnose in Assam. The powdery mildew disease was also affected the growth and yield of chilli in Bastar region.

Management of these diseases through agrochemicals alone is neither cost effective nor environmentally safe. Therefore, an integrated disease management (IDM) approaches, using chemicals, cultural and eco-friendly bioagents are needed for sustainable chilli production (Pandey and Satpathy, 2009; Lydia and Zacharia, 2012). Considering the above effect of IDM on chilli and the impact on diseases management on its yields, we conducted evaluation of integrated disease management against powdery mildew, anthracnose and die back of chilli to find a cost effective method of disease management suitable for Bastar region of Chhattisgarh where chilli is a major remunerative crop for farmers.

\section{Materials and Methods}

The experiments were conducted four farmers fields of Village Malgaon Block Bakawand
District Bastar as four replications at $\mathrm{Sh}$. Tulsiram Sethiya, Sh. Khema Singh, Sh. Jagganath Rai and Sh. Shyamlal Sethiya for two consecutive years 2012-13 and 2013-14 under On Farm Testing through KVK Bastar. The plot size is $100 \mathrm{sqm}$ and spacing of plant to plant and row to row is $30 \times 45 \mathrm{~cm}$ for three chilli varieties Tejaswini (as local) and NS-1701 and VNR-435 (Hybrids) separately. Organic manure was incorporated in the soil and raised beds were prepared, followed by irrigation and covering of beds with polythene sheets $(100 \mu$ thick) for soil solarization during May month.

Neem seed cake mix at $50 \mathrm{~g} / \mathrm{kg}$ cocopit powder for nursery preparation in plastic tray, seed treatment with Tricoderma harzianum at $8 \mathrm{~g} \mathrm{~kg}^{-1}$ seed, Seedling dip in fytolan at 0.25 $\% 1^{-1}$ plus $T$. harzianum at $6 \mathrm{~g} \mathrm{l}^{-1}$, of 20-25 days old seedling and used for transplanting in field and four spray of $T$. harzianum at $4 \mathrm{~g}$ $1^{-1}$ at $35,55,75$ and 110 DAT, one spray of fytolan $\left(0.25 \%^{-1}\right)$ at 90 and one spray of carbendazim $12 \%+$ mencozeb $63 \%$ at $0.25 \%$ at 120 DAT.

\section{Results and Discussion}

\section{Effect of IDM module}

The pooled data of two years 2012-13 and 2013-14 indicated that IDM was effective to check the powdery mildew, anthracnose and die back diseases and increase fruit yields in both hybrid (NS-1701 and VNR -435) and Tejaswini varieties as compared to control in which no use of IDM practice. Mean data shows that per cent disease incidence of powdery mildew, anthracnose on leaves, fruit infection and plant mortality were recorded 3.6, 17.7, 23.0 and 5.6 in IDM used fields and $7.8,33.6,37.7$ and 17.1 in without IDM fields, respectively. The chilli fruit yield was also increased 19.1 per cent in IDM (235.0 q $\left.\mathrm{ha}^{-1}\right)$ as compared without IDM (190.2 q ha $\left.{ }^{-1}\right)$ fields. 
Table.1 Effect of IDM module

\begin{tabular}{|c|c|c|c|c|c|c|c|c|}
\hline Treatments & $\begin{array}{c}\text { Powdery } \\
\text { mildew } \\
\text { incidence } \\
(\%)\end{array}$ & $\begin{array}{c}\text { Per cent } \\
\text { disease } \\
\text { control as } \\
\text { compared } \\
\text { to without } \\
\text { IDM } \\
\end{array}$ & $\begin{array}{c}\text { Anthracnose } \\
\text { incidence on } \\
\text { leaves }(\%)\end{array}$ & $\begin{array}{c}\text { Per cent } \\
\text { disease } \\
\text { control as } \\
\text { compared } \\
\text { to without } \\
\text { IDM } \\
\end{array}$ & $\begin{array}{c}\text { Fruit } \\
\text { infection } \\
(\%)\end{array}$ & $\begin{array}{c}\text { Per cent } \\
\text { disease } \\
\text { control as } \\
\text { compared } \\
\text { to without } \\
\text { IDM } \\
\end{array}$ & $\begin{array}{c}\text { Plant } \\
\text { mortality/die } \\
\text { back }(\%)\end{array}$ & $\begin{array}{c}\text { Per cent } \\
\text { disease } \\
\text { control as } \\
\text { compared } \\
\text { to without } \\
\text { IDM } \\
\end{array}$ \\
\hline NS-1701 with IDM & 2.5 & 60.3 & 13.2 & 40.8 & 16.3 & 47.6 & 4.6 & 55.4 \\
\hline $\begin{array}{l}\text { NS-1701 without } \\
\text { IDM }\end{array}$ & 6.3 & & 22.3 & - & 31.1 & - & 16.1 & - \\
\hline $\begin{array}{l}\text { VNR-435 with } \\
\text { IDM }\end{array}$ & 3.1 & 47.5 & 17.4 & 45.9 & 21.3 & 44.2 & 2.6 & 77.2 \\
\hline $\begin{array}{l}\text { VNR-435 without } \\
\text { IDM }\end{array}$ & 5.9 & & 32.2 & - & 38.2 & - & 11.4 & - \\
\hline $\begin{array}{l}\text { Tejaswini with } \\
\text { IDM }\end{array}$ & 5.1 & 54.5 & 22.6 & 51.2 & 31.4 & 28.5 & 9.7 & 34.4 \\
\hline $\begin{array}{l}\text { Tejaswini without } \\
\text { IDM }\end{array}$ & 11.2 & & 46.3 & - & 43.9 & - & 23.8 & - \\
\hline $\mathrm{CD}(0.05)$ & 1.51 & & 7.92 & & 9.48 & & 5.23 & \\
\hline $\begin{array}{l}\text { Mean of IDM } \\
\text { fields }\end{array}$ & 3.6 & 54.3 & 17.7 & 47.2 & 23.0 & 39.0 & 5.6 & 67.1 \\
\hline $\begin{array}{l}\text { Mean of without } \\
\text { IDM fields }\end{array}$ & 7.8 & & 33.6 & & 37.7 & & 17.1 & \\
\hline
\end{tabular}


Table. 2 Cost benefit ratio

\begin{tabular}{|c|c|c|c|c|c|c|}
\hline Treatments & $\begin{array}{c}\text { Yield (q } \\
\left.\text { ha }^{-1}\right)\end{array}$ & $\begin{array}{c}\text { Percent } \\
\text { Yield } \\
\text { increase } \\
\text { over control }\end{array}$ & $\begin{array}{l}\text { Gross return } \\
\left(\text { Rs. } \text { ha }^{-1}\right)\end{array}$ & $\begin{array}{c}\text { Cost of } \\
\text { Cultivation }^{\left(\text {Rs. ha }^{-1}\right)}\end{array}$ & $\begin{array}{c}\text { Net return } \\
\left(\text { Rs. ha }^{-1}\right)\end{array}$ & $\begin{array}{l}\mathrm{C}: \mathrm{B} \\
\text { ratio }\end{array}$ \\
\hline $\begin{array}{l}\text { NS-1701 with } \\
\text { IDM }\end{array}$ & 252.3 & 15.4 & 151380 & 44460 & 106920 & 2.40 \\
\hline $\begin{array}{l}\text { NS-1701 } \\
\text { without IDM }\end{array}$ & 218.6 & - & 131160 & 39460 & 91700 & 2.32 \\
\hline $\begin{array}{l}\text { VNR-435 with } \\
\text { IDM }\end{array}$ & 243.2 & 27.0 & 145920 & 45760 & 100160 & 2.19 \\
\hline $\begin{array}{l}\text { VNR-435 } \\
\text { without IDM }\end{array}$ & 191.5 & - & 114900 & 40300 & 74600 & 1.85 \\
\hline $\begin{array}{l}\text { Tejaswini with } \\
\text { IDM }\end{array}$ & 209.6 & 30.7 & 125760 & 44780 & 80980 & 1.81 \\
\hline $\begin{array}{l}\text { Tejaswini } \\
\text { without IDM }\end{array}$ & 160.4 & - & 96240 & 40240 & 56000 & 1.39 \\
\hline $\mathrm{CD}(0.05)$ & 12.55 & & & & & \\
\hline $\begin{array}{l}\text { Mean of IDM } \\
\text { fields }\end{array}$ & 235.0 & 19.1 & 141020.0 & 45000 & 96020 & 2.13 \\
\hline $\begin{array}{l}\text { Mean of } \\
\text { without IDM } \\
\text { fields }\end{array}$ & 190.2 & - & 114100.0 & 40000 & 74100 & 1.86 \\
\hline
\end{tabular}

Minimum disease incidences $(2.5 \%, 13.2 \%$, and $16.3 \%$ ) were recorded in variety NS-1701 under IDM used fields of powdery mildew, anthracnose and fruit infection respectively and maximum per cent disease control (60.3 and 47.6) were found in use of IDM practice against the powdery mildew and fruit infection by anthracnose disease.

Highest yield (252.3 $\mathrm{q} \mathrm{ha}^{-1}$ ) was also recorded in variety NS-1701 under IDM used fields as 15.4 per cent higher yield as compared to without IDM. Maximum plant mortality was recorded in variety Tejaswini without IDM $(23.8 \%)$ and with IDM $(9.7 \%)$ used fields and highest yield increase $(30.7 \%)$ was recorded as compared to without IDM.

Champawat and Sharma (2003) found lowest seedling mortality in chilli when seeds were treated with bavistin and soil inoculated with
Tricoderma harzianum and T. viride. Lydia and Zacharia (2012) reported the IDM was found superior to biological and chemical module and reduce disease incidence in Navjyoti and Ujwala varieties.

\section{Cost benefit ratio}

The IDM of chilli diseases we also calculated cost-benefit ratio to see the efficacy of IDM module. We found that IDM module is higher cost effective in variety NS-1701 and found cost-benefit ratio 1:2.40. The mean of IDM practice in all three varieties found higher cost-benefit ratio $(1: 2.13)$ as compared to without IDM fields (1:1.86).

This study found that IDM is a cost effective and eco-friendly approach in the management of powdery mildew and anthracnose diseases in chilli crop. The results of two years on 
farm trials for chilli powdery mildew and anthracnose management resulted in development of an integrated disease management module that included physical methods (soil solarization, seed treatment), biological (use of antagonistic fungus Tricoderma harzianum), and chemical (fytolan, carbendazim and mencozeb) and it was more cost effective as compared to non IDM used fields. Thus, the IDM module is an effective and eco-friendly approach for the management of powdery mildew and anthracnose diseases.

\section{References}

Bosland, P.W. and Votava, E.J. 2003. Peppers: vegetable and spice capsicums. CAB Int., pp.233.

Champawat, R.S. and Sharma, R.S. 2003. Integrated management of nursery diseases in brinjal, chilli, cabbage and onion. J. Mycol. Pl. Pathol., 33: 290291.

Chowdhury, S. 1957. Studies on the development and control of fruit rot of chillies. Indian Phytopath., 10: 55-61.

Kim, K.H., Yoon, J.B., Park, H.G., Park, E.W. and Kim, Y.H. 2004. Structural modifications and programmed cell death of chilli pepper fruit related to resistance responses to Colletotrichum gloeosporioides infection. Phytopathol., 94: 1295-1304.

Lydia, C. and Zachariah, S. 2012. Evaluation of biological, chemical and IDM modules for the management of anthracnose and die-back of chilli. $J$. Mycol. Pl. Pathol., 42(4): 435-438.

Manandhar, J.B., Hartman, G.L. and Wang, T.C. 1995. Anthracnose development on pepper fruits inoculated with Colletotrichum gloeosporioides. $P l$. Dis., 79: 380-383.

Pandey, K.K. and Satpathy, S. 2009. Development of integrated pest management in chilli against major diseases and insect pests. Ind. J. Pl. Prot., 37: 104-110.

Sydow, H. 1913. Beitrage Zur kenntnis der pilzflora des sudlichen Ostindiens I. Ann. Mycologia., 11: 329-330.

\section{How to cite this article:}

Yadav, S.C., S.C. Mukherjee and Netam, R.S. 2017. Evaluation of Integrated Disease Management Practices against the Powdery Mildew, Anthracnose and Die back Diseases of Chilli Int.J.Curr.Microbiol.App.Sci. 6(2): 1129-1133.

doi: http://dx.doi.org/10.20546/ijcmas.2017.602.127 